\title{
The south in the world
}

\author{
Elleke Boehmer
}

In Herman Melville's huge and perennially remarkable novel Moby-Dick (1851), the fateful Pequod with Captain Ahab at the helm pursues his nemesis the eponymous white whale from the Atlantic through the Southern Ocean and the Indonesian archipelago into the South Seas. As it does so, its heterogeneous crew crosses paths with a number of other whalers, including the Goney (or the Albatross) and the Rachel. These are fortuitous crossings in those weltering immensities, yet each whaler is met with a sense of fateful inevitability and each encounter is heavy with inarticulate surmise and expectation. The crews as they pass one another have the impression that these vast southern immensities throw up north-south conjunctions. However, as profound is the feeling that the far extremities of the great oceans defy attempts to circumscribe and understand their immensity, especially those pitched from the north, represented here by Ahab. The narrator Ishmael's friend Queequeg, the tattooed Fijian, by contrast, is in his element for much of the Pequod's journey. Yet he too, idol-worshipping and superstitious, is typecast according to northern conventions. ${ }^{1}$

As Worlding the South explores, southern hemisphere histories are threaded through with many tenuous and yet still tenacious human conjunctions like the Pequod's - conjunctions often realised in or crystallised through maps, books, letters, panoramas, and other kinds of inscription and installation. These verbal, textual, and cartographic networks the book's contributors study in abundant, fascinating detail. As against the monolithic constructs of empire and nation of much nineteenth- and twentieth-century colonial history, the editors Sarah Comyn and Porscha Fermanis offer this transnational, transactional, and latitudinal south-centred project - one that zigzags through and across the nineteenth-century British world, but without at any point reifying it as a construct. The book puts in place a critical exercise of worlding, or, more properly, re-worlding, which is conceived as a double movement both of showing how the south was made into a knowable global object and of unravelling the representational strategies and entangled histories that made the south conceivable in this way. This 
endeavour allows the editors and contributors to deprioritise imperial orientations and identities in favour of southern perspectives, bringing in different circuits of production and alternative temporalities, including from Black and Indigenous worlds. Worlding as a methodology thus encourages the contributors critically to probe and re-examine how the world has been naturalised historically and invites contrapuntal, southern perspectives to come to the fore.

Each one of the book's eighteen detailed case studies contributes from its particular regional and methodological vantage point to this series of double movements, tracing from multiple different perspectives the gradual knitting of the lands, islands, and oceans of the British-governed southern hemisphere into the institutions of colonial modernity. From the late eighteenth century and the arrival in 1788 of the First Fleet on the east coast of the Australian continent, we see the widely separated spaces of the south stochastically folded into what Immanuel Wallerstein described as the one but uneven capitalist world, and we observe how local Black and Indigenous knowledge is often occluded, mistaken, overwritten, and erased as a result. ${ }^{2}$ At the same time, we track the funnelling of human populations and communities through and around the shapes and contours of the southern hemisphere's main land masses and archipelagos - an important, age-old process, as Barry Lopez highlights in Arctic Dreams (1986): 'the way landscape funnels human movement, such that encounters with strangers are half expected', as they are on the Pequod. ${ }^{3}$ The essays further trace the long-distance journeys not only of commodities and newspapers, but also of fads and fashions that refract from the metropolis to the Antipodes and then sometimes bounce from the colonies back to London, as wittily narrated, for example, in Clara Tuite's study of the Regency yet also antipodean cult of the dandy.

Worlding the South critically analyses from its range of regional, histori$\mathrm{cal}$, and theoretical vantage points the combination of forces including trade, commerce, emigration, and travel through which the south was worlded - an external, objectifying process. But it also considers how the south might be reimagined from within. We focus on southern subjectivities, orientations, and perspectives - in short, worldings - and use these to attempt to rethink British or metropolitan hegemonies. We see how southern worlds emerge piece by piece from these different processes of knowledgegathering and exchange, and then how critical re-reading might undo these Eurocentric and often imperial inscriptions.

Responding to the double movement that the book encourages, it is worth interchanging its core titular terms for a moment, or, as it were, spinning its poles, to ask what 'the south' was that was 'worlded' in these ways? What did and does this south comprise? How was and is it in actual fact 
lived and perceived? This may be a more provocative question - one that is probably too far-reaching to address satisfactorily in a book-ending chapter. ${ }^{4}$ How the worlds of the south might themselves be set up epistemologically, what southern experience might entail, and how it is understood is dealt with more implicitly in these pages, perhaps unavoidably so, in what is a literary historical project first and foremost.

Indeed, I would venture to say, there is something about the study of southern worlds that might by definition have to remain always beyond our analytic reach. For the south ultimately far eludes the indices of otherness that scholars of different global souths have instated as compensatory shorthand for the southern hemisphere's alternative temporalities, as Comyn and Fermanis write. This chapter, 'The south in the world', tries to give a few tentative answers of its own to those questions of southness by offering a meditation in closing on some of the more elusive meanings of the south that the collection calls up, inspired by the same critical orientations that it explores. For reasons that I clarify further in later sections of the chapter, I begin by turning first to a cluster of literary writings from the south and, in particular, to the implications and glimmerings of alternative worlds they open to the reader. Without in any sense reinstating institutions of literature that have been largely northern in provenance and repressive in application, I contend that it is through the border-traversing, world-opening capacities of southern writing and reading that new perspectives on the south may be sparked. ${ }^{5}$ In a word, re-worlding crucially begins with the insights of imaginative writing.

\section{The south as 'sea country'}

The southern-hemisphere novelist J. M. Coetzee, South African-born, now Australian, has audaciously suggested in recent years that there is only 'one south', a 'unique world' that seems, from his perspective, to circle the southern subtropics. In these spaces, he has evocatively yet cryptically written, 'the winds blow in a certain way and the leaves fall in a certain way and the sun beats down in a certain way that is instantly recognisable from one part of the South to another'. ${ }^{6}$ As in his Jesus novel trilogy (2013-19), set in a fictional Southern Cone or Chile-like country, this south is remote, provincial, derivative, and Spanish-speaking. The region forms the final destination on a complicated but undisclosed migration route across the ocean that appears to strip migrant characters of any memory of their former homelands. ${ }^{7}$ Key features such as climate manifest laterally in this cross-continental world, uniting its inhabitants through a framework of mutual recognition. (Indeed, the southern subtropical zone Coetzee appears to outline in actuality forms 
the most inhabited part of the hemisphere.) We notice, however, the extent to which this 'one south' defies expression, even for a writer as magisterially fluent as Coetzee. It can only be designated in so many unspecific phrases: 'in a certain way ... in a certain way ... in a certain way'.

For Indigenous Australian writer Alexis Wright in her phantasmagoric epic Carpentaria (2006), set in the Gulf country of north-western Queensland, the south is at times the place from which corrupt and out-of-touch Canberra politicians and their edicts issue. At a significant point in the novel, bushfires enflame the southern horizon, confirming it as a hostile zone. ${ }^{8}$ Mostly, though, visions of 'seas of oceans' shared by elders, like Norm Phantom, and their heirs erase north-south as well as past-future divides. Country including 'sea country' subsumes such distinctions, as another elder, Joseph Midnight, openly recognises, while he at the same time interestingly denies the existence of a present-day or 'contemporary world'. To him, future and past are co-present: 'It's the same world as I live in, and before that, and before that. No such thing as a contemporary world.' Song and performances co-exist within and call up this continuous and living space-time though only if 'remembered in the right sequence where the sea was alive, waves were alive, currents alive, even the clouds'. ${ }^{9}$ As a caution to all northern travellers and presumably scholars, too, this is country that will only allow us to move through it where it 'lets' us through.

In contrast to Wright's borderless vision of a tropical 'sea country', the Western Australian writer Tim Winton for his part tends to see the southern lands, seas, and skies he hymns in his fiction through a determinedly regional, specifically Western Australian, lens. Yet many of his enthused observations of these desert landscapes and ocean views are, at the same time, distinctively southern in a far broader and more ecumenical sense. As he writes in Island Home (2015): 'The white southern beaches won me over. They were the purest, the least trammelled and the loveliest I'd ever seen. And there were so many of them. ${ }^{10}$ Yet, we might immediately observe, many littorals of the southern oceans feature such beaches. They are not exclusive to his continent. From Winton's impassioned descriptions of what he sees as his country a strong sense of the south in the world thus arises obliquely, as if through cracks in the lens, as again in the following:

In Australia the sky is not the safe enclosing canopy it appears to be elsewhere. It's the scantiest membrane imaginable, barely sufficient as a barrier between earthbound creatures and eternity. Standing alone at dawn on the Nullarbor, or out on a saltpan the size of a small country, you feel a twinge of terror because the sky seems to go on forever. It has perilous depths and oceanic movements. In our hemisphere the sky stops you in your tracks, derails your thoughts, unmoors you from where you were going before it got you by the collar. ${ }^{11}$ 
Notice how the description modulates from claiming such skies for Australia to allowing them to widen across 'our hemisphere'. Yes, and ... the southern reader of this passage would want to observe, feeling the impact of the evocation, recognising that depth of sky Winton is talking about, yet doing so from any number of possible vantage points across the south: not only the Nullarbor but also the Atacama, the Karoo, the Namib desert (all notable dark-sky sites across the hemisphere). Incidentally, the word saltpan, from Dutch through Afrikaans, nicely clinches the point. Winton needs to borrow a word from another southern world to describe a southern feature that forms a fundamental part of his sensory experience of the south.

Turning to my own fictional maps of the south for a moment, my 2019 short-story collection To the Volcano tries to capture from a range of different viewpoints similar latitudinal moments of southern awareness. ${ }^{12}$ Stories set across the south - in Australia, South Africa, Zimbabwe, Botswana, and Argentina - reflect upon a distinctive southern sensorium while also registering aslant the south's histories of violence and dispossession. These moments of awareness - of distance, transit, haunting, ice-blue light, and 'seething' lands that elude naming - are spaced out across the south, and across the collection. Yet they remain horizontally connected, mapping intersecting contours of southern affinity. This project of navigation through story is supported at a formal level by the shape of the short-story collection itself - its pluricentredness permits effects of both dispersal and collocation, as also in the writing of Louis Becke, discussed in these pages, and indeed of his near contemporary the New Zealand-born Katherine Mansfield. The metaphor of the archipelago will unsurprisingly return later in this chapter via Epeli Hau'ofa as a particularly suggestive vehicle of southern understanding.

As I have demonstrated here by literary example, exploring the south in or of the world means registering an important caveat. To understand southern worlds, we need to tune into southern languages, notations, and perceptions. Conversely, properly conceiving of the southern hemisphere using northern conceptual tools may be challenging, not to say impossible, without extensive linguistic and anthropological work, all of it latitudinal, translational, and comparative - probably more thoroughgoing work than any one book can deliver. To date, geo-epistemological questions setting the south in relation to the rest of the world have almost invariably been northern or north-centred, in the sense that they are not only constructs of northern imaginations but also assume an interpretive perspective directed from that hemisphere, as we will see again. It is no accident that the southern writers I have cited in illustration all use versions of global literary English to evoke their southern contexts. Though they may speak first to southern readers, they all also have in mind global audiences who tend to see the world through northern frameworks. 


\section{Southern spaces, northern frameworks}

Geographies ceaselessly shape human history. In the southern hemisphere, the dominant, history-moulding land masses comprise the two great continents running north-south of South America and Africa, the island-continent of Australia, with the until recently uninhabited, slightly larger island-continent Antarctica to the south, at the Pole, and in the Pacific, and to a lesser extent the Indian Ocean, various larger and smaller island clusters. Some geographers hold that there is a fifth southern continent, Zealandia, or Tasmantis, a submerged continental crust of which the islands of New Zealand form a central spine. All of these land masses together (as well as India) formed part of the great southern continent, Gondwanaland, which broke up about 80 million years ago: they still bear signs of having undergone similar processes of glaciation. Vegetation in one remote part is often related to that in another part, as we find with the Kerguelen cabbage, for example, that grows on the Indian Ocean island of that name and is also found in the higher latitudes of South America. ${ }^{13}$

Sketching these spaces in our minds or on the world map, we immediately notice that the southern hemisphere lacks its northern counterpart's great east-west land bridge of Eurasia, with the further possibilities for cross-continental movement into the Americas of the once frozen Bering Sea, which narrowly separates Asia and Alaska. In the southern hemisphere, all traffic between the continents and islands is necessarily across oceans; all migration was traditionally by sea. Lopez's funnelling of populations through and across land masses always tends to operate north-south. Till the age of jet travel and even beyond, the southern journeys of rafts, canoes, and ships were often both isolating and precarious, as the Pequod's crew many times discovers. Yet, despite these very different southern arrangements, it is according to northern processes and paradigms that the south is predominantly understood.

Most of the contributors to this book to a greater or lesser extent share these northern perspectives, willy-nilly, including the writer of this chapter, southern-born though many of us are. Symptomatically, the editors' introduction draws in the main on northern literary-critical discourses to set up its theoretical scaffolding. And how could it not? It is almost impossible, or, better said, conceptually intractable, for any research largely located in western or northern institutions of learning entirely or even substantially to unthink or dismantle this inflection. This needs to be properly recognised if our researches on the south are to be true - even if tangentially - to the south's Indigenous and Black realities, as well as respectful of its epistemological elusiveness.

To expand on this further, seeing the south in the world necessarily means viewing it through the lenses of the northern academy, located in educational 
institutions and pedagogic traditions that have developed in the north. Southern worlds, including the world that is the Global South - a development designation with a similar valence to the now outmoded 'Third World' have generally been explained using northern analytical tools. It was and still is in the northern hemisphere, across its temperate zones, that many of the centres and archives of authoritative knowledge about the world (including the south) lie. It is in the north that the greatest number of professional scholars remains concentrated. The dominant technologies through which the south is studied are northern in provenance - they have been so since the late 1400s, and further back even than that, if China and India are deemed northern also (which they are, of course, in hemispheric terms). Even northsouth global divides are northern constructs. As the editors remind us, far from being 'a pre-defined ... conceptual category', the south began as a European discursive production.

In short, for at least six centuries, since Vasco Da Gama rounded the Cape of Good Hope to reach India in 1497-98, and the Ferdinand Magellan and Juan Sebastián Elcano expedition circumnavigated the globe in 1521-22, the world as a whole, including the southern hemisphere, has generally been understood from the vantage point of the north. This is not to say, of course, that southern spaces have not produced great thinkers, navigators, discoverers, and scholars across those centuries and before. It is rather that in the annals of world history their names do not carry value. They do not feature prominently, if at all, in part because of the complex and destructive effects of the different waves of empire that have swept across the world from the north, in part because, as a result, those annals have been produced there. Happily, this emphasis may now be shifting with renewed attention being given, for example, to the crucial navigational expertise of the Tahitians Tupaia and Mai, who travelled with Captain James Cook on his first, and second and third voyages respectively, or to the role of Indigenous and Black petitioners and translators in nineteenth-century rights campaigns, such as the South African Gonaqua Andries Stoffels, among those named in Hlonipha Mokoena's essay. ${ }^{14}$

Indicatively, the world as first seen from space showed the South Pole 'at the top', but the image was inverted when it was first published. To have the north uppermost and dominant is the accepted view, concurring with normative world maps. Northerners, who as we already know make up most of the world's population, rarely have reason to view the south in any other way. This would apply especially to those northerners who have not visited the south, a significant majority within that majority. The relativising antipodean perspectives aired in Australian newspapers and periodicals that Comyn discusses in Chapter 2 infrequently constituted a northern pastime.

From the time of Bartolomeu Dias and Vasco Da Gama, northerners have been indifferent to the south unless it offered promises of wealth to be 
exploited, as did mining or whaling. Hence the importance of a collection such as this, which insists on dislodging such entrenched lines of sight by contemplating the world from the various perspectives and orientations of its different southerly regions and their histories. The project is extremely ambitious, even within the geo-political delimitations of the category signalled in the subtitle, the 'southern settler colonies'.

From this recognition of what might be termed southern heuristics the question arises, how then practically speaking do we go about studying the south? If the south cannot be perceived outside of northern terminologies, does this not effectively set 'the real south' and its far peripheries at a remove from analytic understanding, at a remove even from a collection of case studies on the south $?^{15}$ As we see, for example, in the several chapters investigating efforts by southerners over time to convey and explain something of their southern environments to northerners, such as Kiro or Kōhere (or, I would add, in respect of South America, Jeremy Button of Tierra del Fuego on board the Beagle), is it necessary to translate and thereby inevitably filter and adapt ideas of the past and future, history and geography, through northern languages and allegorical models to do so?

Even eloquently transmigrated texts, such as the Māori writer and petitioner Kōhere's allegorical inflection through Thomas Babington Macaulay of Māori land claims, speak in 'distinct, conflicting voices', as Nikki Hessell observes. Efforts to 're-territorialise' global intellectual production are ethically all very well and to be encouraged. However, the project of undoing the legacies of colonial knowledge making and 'related understandings of southness', as the editors write, represents a significant philosophical challenge, further complicated by economic and infrastructural inequalities, given the relative material poverty of many countries in the south. This impelled my turn above to literary writing with its suggestive metaphorical and rhythmic effects to capture something of the south. Put simply, critical theory that is necessarily predicated on dominant northern constructs cannot get us there.

On northern self-construction, it is also important to recognise that the south is not just another version of the Orient, a projection by metropolitan cultures on to the lands beyond the equator. In that sense it entirely escapes the category of 'uncanny temporal figure' the editors cite, alluding to the Comaroffs, Harry Harootunian, and others. It does not bear analogy with the fabulous east, at once desired and feared by a rapacious west, within that polarised imperial dynamic that Edward Said famously defined. ${ }^{16}$ If, according to the timelines of the north or west, the east was degenerate and Africa backward, if the former lagged behind and the latter had not yet mounted the scale of civilisation, the south, by contrast, was nowhere on or near this scale. Far distant geographically, it was also seen as far distant in 
time, lying entirely outside the chronologies of the north. If the north had temporality, the south was anthropology, to adapt from Johannes Fabian's Time and the Other (1983). ${ }^{17}$ The south was always the raw to the north's cooked.

As a further illustration of this conceptual and historical remoteness, we might remember the number of times in this collection that individuals, products, and papers reach the north and gain recognition and comprehensibility only through this process of arrival. Before, they formed part of a story or a myth; now they became verifiable fact. The artist-explorer Thomas Baines, discussed by Lindy Stiebel in Chapter 10, for instance, took pains to present his finished coronation map of Zululand to the Royal Geographical Society in London in 1874, and this duly secured his election to the Society as Honorary Fellow for life. Though his mapmaking and prospecting journeys took in much of southern Africa and included a trip to northern Australia, the professional recognition for his work in and across the south had to come from the centre. So, too, as Manu Samriti Chander observes in his study of Guianese reading publics, educational recognition for Creole elites in British Guiana could be bestowed only by London. Meanwhile, within the imperial hierarchical scale, as he also writes, the Indigenous peoples of the colony were deemed 'ontologically illiterate'.

\section{The clustered and multi-textured south}

In their wide-ranging and comprehensive introduction, Comyn and Fermanis approach the south as an assemblage of the southern colonies of the British world that together provide occasion for developing overarching synthesising frameworks from worlding through to hemispheric analysis. But this is not all. The southern spaces they draw together, they further interconnect historically and thematically, first, through investigating the experiences of 'imperialism, settler and mercantile colonialism' that have linked these spaces, and, second, through exploring a 'set of shared thematic concerns, literary forms and tropes' that may be said to be 'distinctive (although not always exclusive) to the region', and that demonstrate plasticity across it. In these ways, they open roads to re-worlding. In the case studies collected here, these forms and motifs include the female testimonial, the letter, the short story, documents of settlement and enclosure, and tropes of antipodal inversion - this last curiously more prevalent in Australian writing than, say, in South African or New Zealand.

Broadly speaking, then, the editors' south forms an overarching analytic construct validated by colonial history and seemingly corroborated in shared and overlapping cultural and aesthetic practices, traced in more detail in some of the chapters. It is by building transnational and transoceanic 
frameworks while at the same time addressing local, fluid, and peripheral perceptions that their project endeavours to resist, on the one hand, the exclusive 'metropolitan-dominated' tendencies of settler colony studies and, on the other, the nation-centred focus of literary histories. At moments, it is true, the enterprise of theorising the south by a layering on of hypotheses can appear to be at disciplinary or methodological cross-purposes, though the vigilant critical project of worlding and re-worlding (and re-wording) mitigates the 'supra-planetary' nature of the endeavour. Southness will perhaps always elude northern analysis to some degree, its local and Indigenous detail always slipping just beyond the frame. This is particularly the case, once again, when historiographies of the south operate across sharp hierarchical gradients. Top-down global southern analysis is inimical to doing lateral or south-south comparative work.

How do the eighteen chapters that make up Worlding the South see the south in the world? The southern hemisphere that the case studies map is geographically multi-textured, the lands, regions, and islands within its four (or five) continents and their surrounding oceans drawn into a loosely connected and dynamic British world network stretching from Guyana to Malaysia and the South Pacific. Each chapter explores a corner, cluster, centre, or connection within this fluid hemisphere, tracing how it was brought into global structures of knowledge that include the panorama, the coronation map, and the printing office. Fariha Shaikh and Michelle Elleray, for example, observing how mobile imperial subjectivities shifted between Britain and Australia, and the Cook Islands and Britain, respectively, examine the technologies of newspaper production and bible translation that were 'actively involved' in their production.

Intriguing entanglements, switchbacks, and lateral connections emerge from many of the readings, such as when Louis Becke's stories in Jennifer Fuller's study can be seen to mobilise an understanding of Pacific islands as at once totality and network, following Epeli Hau'ofa. Stretching these connections latitudinally across other chapters, emigrant ships to Australia are found to be built of Burmese teak, as in Shaikh, while, in Elleray's account, the Cook Islander Kiro helps London Missionary Society members in London with translating the Bible into Cook Islands Māori.

Ingrid Horrocks on the peripatetic artist Augustus Earle in New Zealand further develops this central model of mobility. She persuasively points out that when contact or encounter such as between Māori and Pākehā is framed as fluid and interactive rather than conflictual and binary, both sides to the encounter become contemporary to each other. We move away from the view that one party is frozen in time in relation to the other, as if 'waiting to be visited, observed, and eventually colonised' by the 'traveller-artist-anthropologist-colonist'. Jason Rudy et al. extend such lateral southern connections in 
their study of the remarkable expatriate and utopian Australian community of Colonia Cosme in 1890s Paraguay. In this case, once again, the Cosme Monthly with its insets of poetry and song worked as a technology that gave shape and expression to this transplanted southern colony.

For many contributors, interestingly, the nation, or, more precisely, the nation in formation, remains a prevalent category of analysis, even in spite of the editors' transnational emphases. Especially where countries of the south remained peripheral to imperial and neo-imperial global markets, the nation continued to be an important site of economic planning and cultural mobilisation. Jane Stafford, for example, explores how Defoe's Robinson Crusoe was read as a settler parable for colonial New Zealand, and not only by Pākehā. Ken Gelder and Rachael Weaver in 'The Transnational Kangaroo Hunt' discuss kangaroos as objects, specimens, and actual animals that disseminated a certain idea of Australian and antipodean typicality abroad. Many of the mobile documents discussed in these pages, including newspapers, maps, and translated bibles, played a role in embedding and concretising the shape of the nation in different colonial spaces. As Lindy Stiebel finds, Thomas Baines' coronation map of Zululand entrenched the idea of the Zulu nation to the degree that when the Anglo-Zulu War broke out in 1879, there was for the British 'a visible country to be conquered'.

Overall, the south in this collection emerges more in the breach than from direct observation, more from looking past than looking at - as might stand to reason. For Fermanis and Comyn, the perceptual south grows out of and yet evades a predictive 'vertical hierarchy' of 'above and below'. It gleams from between the lines, as in the literary examples cited earlier. Similarly, new critical understanding shines out fitfully from between the Indigenous words and glosses in Eliza Dunlop's far-sighted 1838 poem 'The Aboriginal Mother', as Anna Johnston demonstrates.

Many of the chapters draw out southern viewpoints by bearing down on local and specific detail, to avoid the risk to their heuristic focus that more comparative but inevitably also more homogenising work across southern spaces might bring. Such close involvement, as demonstrated in Grace Moore's study of the nineteenth-century botanist and fiction-writer Louisa Atkinson, for instance, allows a fuller understanding of, in this case, Atkinson's complicated respect for the bush to emerge. Atkinson in Moore's description learns, even if only partially, to see the land as a formative space for all of its inhabitants. An equally conflicted sympathy comes through in the English naturalist William Burchell's travel writing, discussed in Matthew Shum's chapter, such as when Burchell sitting down with local Khoisan people observes that: even 'in the midst of this horde ... I had been one of them'.

To see the south in the world means looking to the side, beyond 'centres in modernity', towards 'composite and overlapping' Black and Indigenous 
realities - or 'the more fluid worlds of the southern hemisphere', to quote Peter Otto in his chapter on the Sydney panorama. Working within such southern interstices we evade to some extent the static ontological binaries of twentieth-century colonial theory, and so challenge the hegemony of 'literary worlds' framed in terms of copies and originals, as discussed in Eric Hayot's compelling analysis..$^{18}$ Off-beam, oblique, and liquid southern perspectives transform embedded views of the colonial encounter cast as mobile Europeans meeting sedentary Indigenous people caught in the waiting-room of history, to refer once again to Horrocks via Dipesh Chakrabarty. ${ }^{19}$ The recognition that then emerges, of the 'radical contemporaneity' of 'coeval others' across the south and the 'co-presence of [their] simultaneous diverging narratives', is perhaps one of the most distinctive and heuristically powerful of the southern perspectives and re-worldings explored in these pages.

Criss-crossed navigational routes, career pathways, lines of knowledge making, and newspaper dissemination - southern networks in Worlding the South are almost by definition partial and patchy. Missing connections and fortuitous link-ups are part of their looseness and contingency. But this looseness also means that they thereby allow creative adaptation and reappropriation. Though ideas often arrived in the south second-hand, as Mokoena observes, at the same time they were susceptible to alteration and regeneration, especially at those places of looseness and rupture. Tracey Banivanua Mar, Nadia Rhook, and others influentially demonstrate in their research that resistance emerges out of the structural flaws, gaps, broken links, and ellipses that are endemic to any colonial-type assertion of planetary consciousness. Or, as Mokoena goes on to say: 'It is in these rebellions that one hears the voices of the Africans who were petitioning the British government in their own words.'

The south in these pages manifests again and again as an assemblage of heterogeneous spaces and locales - ships' decks and hills of green stones and arid interiors and rocky atolls and caves in rocks and the 'boundless aerial spaces' that Burchell observes on his travels (I pick and cite at random) - spaces that are interconnected across vast distances and at many levels by mobile subjects of all kinds. ${ }^{20}$ This south both invites and makes possible archipelagic reading: the kind of approach that Fuller recommends for Becke's Pacific short stories can be expanded to the entire constellated collection. Holistic archipelagic reading, as the Pacific islands theorist Epeli Hau'ofa observes, respects the character of the south by channelling how its oceanic energies interact with and sweep around its land-masses. It invites us to think 'pluricentrically', to quote Fermanis in her study of the Straits Chinese Magazine. It sheds light on interlaced oceans, lands, and islands 'in the totality of their relationships' ${ }^{21}$

It may be, then, that the idea of the archipelago finally brings us closer than any other heuristic device to the 'certain something' of the south. Or, at least, it allows us to perceive the south in ways that are truly southern (at 
least to the extent that we can tell), that resonate with its uneven and intertwined spatial, atmospheric, and political arrangements, that can properly be termed 'epistemologies of the south', in Boaventura de Sousa Santos' term. Archipelagic heuristics support this book's task of re-angling the literary lenses of the nineteenth-century British literary world in order properly to bring in the stories, interpretations, and agency of the southern colonies and their peoples. The archipelago invites us to think connectively and fluidly through and across the spaces of the south, following and retracing as we do so the many mazy lines that the chapters in this collection have made available to us. The archipelagic view also resists the centre-periphery models that have always been inflicted on the south; it explodes restrictive concentric arrangements of original and copy.

In imagination, reading the south in clustered and multicentred ways tunes us into the hemisphere's vast 'sea country' and its scattered lands and meandering coastlines, echoing and funnelling their particular shapes, flows, and densities - shapes that in turn might be said to mirror the brilliant constellations of its radiant night skies, the Milky Way's 'fierce field of light'. ${ }^{22}$ An archipelagic perspective allows us to envision the scattered lands and islands of the south once again as dispersed fragments of the ancient great mass of Gondwanaland, puzzle pieces of the continent, sea-washed parts of the main. By thinking different spaces within the one metaphoric frame of the archipelago we plot virtual connection in a resonant, multi-axial, defiantly southern way, gathering singularities into clustered patterns that militate against any idea of a world imposed from above.

\section{Notes}

1 See Herman Melville, Moby-Dick, ed. H. Beaver (London: Penguin, 1986). Indeed, it is factually true that the southern hemisphere across history and into the present day is less inhabited, bearing only $11 \%$ of the world's 7.3 billion people. The antipodean hemisphere is also significantly more fluid and bluer, holding $80 \%$ of ocean to the north's $60 \%$.

2 Immanuel Wallerstein, Historical Capitalism with Capitalist Civilization (London: Verso, 1996).

3 Barry Lopez, Arctic Dreams (1986; London: Vintage, 2014), p. 258. See also the more recent Horizon (2019) with its further speculations about travel across great distances.

4 I try to answer it at greater length in a new study, a literary and cultural history of responses to the southern hemisphere, with the working title Southern Imagining (forthcoming). See also my discussion of southness in Elleke Boehmer, The Shouting in the Dark and Other Southern Writing (Crawley: UWA Publishing, 2019), pp. 241-92. 
5 See the discussions of reading for relevance and the capacity of literature to keep refreshing how we understand the world in Elleke Boehmer, Postcolonial Poetics: 21st-Century Critical Readings (Basingstoke: Palgrave Macmillan, 2018).

6 James Halford, 'Southern Conversations: J. M. Coetzee in Buenos Aires', Sydney Review of Books (28 February 2017), n.p., https://sydneyreviewofbooks.com/ essay/southern-conversations-j-m-coetzee-in-buenos-aires/ (accessed 1 May 2020).

7 See J. M. Coetzee, The Childhood of Jesus, The Schooldays of Jesus, The Death of Jesus (London: Harvill Secker, 2013, 2016, 2019).

8 Alexis Wright, Carpentaria (Sydney: Giramondo Press, 2006), pp. 375-82.

9 Wright, Carpentaria, pp. 375-8.

10 Tim Winton, Island Home (Sydney: Penguin Random House Australia, 2015), p. 173.

11 Winton, Island Home, p. 18.

12 Elleke Boehmer, To the Volcano (Brighton: Myriad Editions, 2019), esp. pp. 28, 41 .

13 Kate Teltscher, Palace of Palms: Tropical Dreams and the Making of Kew (London: Picador, 2020), p. 84. See also Nicholas Shakespeare, In Tasmania (New York: Overlook Press, 2004).

14 Kate Fullagar, The Warrior, the Voyager and the Artist: Three Lives in an Age of Empire (Yale: Yale University Press, 2020).

15 Elleke Boehmer, Colonial and Postcolonial Literature: Migrant Metaphors (Oxford: Oxford University Press, 2005), chapter 1. See also my efforts to interrogate centre-periphery models of empire by working laterally in Empire, the National, and the Postcolonial: Resistance in Interaction (Oxford and New York: Oxford University Press, 2002).

16 Edward Said, Orientalism (London: Pantheon, 1978).

17 Johannes Fabian, Time and the Other: How Anthropology Makes Its Object, foreword Matti Bunzl (New York: Columbia University Press, 2002).

18 Eric Hayot, On Literary Worlds (Oxford: Oxford University Press, 2012).

19 Dipesh Chakrabarty, Provincializing Europe (Princeton: Princeton University Press, 2000).

20 See Antoinette Burton and Isabel Hofmeyr, 'Introduction', in Antoinette Burton and Isabel Hofmeyr (eds), Ten Books That Shaped the British Empire: Creating an Imperial Commons (Durham: Duke University Press, 2014), p. 1.

21 Epeli Hau'ofa, We Are the Ocean: Selected Works (Honolulu: University of Hawai'i Press, 2008), p. 31.

22 Wright, Carpentaria, pp. 378-80; Tim Winton, The Boy behind the Curtain (Sydney: Penguin Random House Australia, 2016), p. 75. 